\title{
Instructional Leadership Based on Theory of Planned Behaviors In Improving Nuring Students 'Commulative Achievement Index (GPA)
}

\author{
Sheylla Septina Margaretta*, Ely Isnaeni \\ Institut Ilmu Kesehatan Bhakti Wiyata, Indonesia \\ *sheylla.margaretta@iik.ac.id
}

\begin{abstract}
Professional nurses are required to have good academic experience so that good learning management is needed in the nursing study program to manage all aspects of the campus environment which are expected to increase academic scores according to professional standards. One of the milestones of the study program's objectives is good leadership so that in the learning process it is necessary to have leadership management references, one of which is the application of Intructional Leadership Based on Theory of Planned Behavior. The purpose of this study was to determine the effect of Instructional Leadership with the Theory Planned Behavior (TPB) approach on increasing the Academic Achievement Index (GPA) of new students in the undergraduate nursing study program. The method used is a quantitative method using a pre-experimental design with the type of one group pre-post test, the application of instructional leadership is carried out by the Head of Study Program for one semester with the GPA assessment using observations through the GPA transcript value. The sampling design used a total sampling technique, namely 63 students in semester 1 . The results of the study through the paired t-test obtained a significant value of $p=0.000$ on the student's GPA. The conclusion of this study is that the application of Instructional Leadership with the TPB approach can increase student GPA. This research can be applied by the Head of Study Program in carrying out its duties and functions so that it can improve student academic achievement.
\end{abstract}

Keywords: Intructional Leadership, Theory Planned Behavior, Achievement Index, Nursing Students 


\section{STRADA Jurnal Ilmiah Kesehatan}

DOI: $10.30994 /$ sjik.v9i2.488

ISSN: 2252-3847 (print); 2614-350X (online)

Vol.9 No.2 November 2020 Page.1445-1456

\section{BACKGROUND}

The need for professional nurses is increasing every year. The demands for the needs of care personnel are based on the needs of the community for health services. The increase in the population is accompanied by an aging process of human life, so it is necessary to have an important role for professional nurses in helping to provide nursing care to alleviate the pain of individuals and vulnerable groups in society. The role of professional nurses is very important in the sustainability of providing adequate health services, so that in pursuing education, prospective nurses will be required to be competent and competent. Nursing education is taken for 5 years, that is, four years will lead to the undergraduate level with a total of 8 semesters and will be continued for 1 year at the Nurse level for a total of 2 semesters. Based on research, student nurses at the final level have thoughts on professional career life that will be pursued in the future, namely nurses must have an ethical tolerance to help those who need nursing care assistance, have a soul to protect and develop nursing care for patients. Based on the research results, nursing students also need a reflexive and supportive work culture in their future work careers (Hägg-Martinell A et al, 2020).

In addition to the view of career life according to Holmgren, J (2017), the professional task of global nurse analysis is the development of knowledge about health, care, disease and ecology in the local and global context. The nursing profile characterizes individuals with advocacy skills, activism and a spirit of sustainable development. The attainment of knowledge in academic education is used in upholding human norms to get society to get social justice. So it can be concluded that nursing knowledge globally aims to reduce the morbidity of individuals and communities, maintain human dignity and contribute to health for current and future generations.

The goal of becoming a nurse is pursued in campus and clinical education. In curriculum education on campus students are provided with theoretical knowledge and learn to use laboratory equipment. Apart from being on campus, clinical learners are also carried out in hospitals and health centers. So that nurses are required to be able to work together with a team of nurses and other medical personnel, one of which is a doctor. Based on the results of research on 1,024 samples of nurses. Nurses need effective communication within the nursing team and with doctors. This shows the nurse with high satisfaction if they can work with teams and collaborate with doctors. So it can be concluded that managerial strategies to promote nurse collaboration with the team and with other medical personnel are important to increase the effective commitment of nurses to the team (Galletta, M et al, 2016) and two years later retrospective interviews were conducted with nurse students, it was found that nurse students learned to adapt to the hospital environment, learned to manage stress to create an adaptive learning environment structure, building therapeutic interaction relationships with patients, practicing independently in the nursing unit, and taking responsibility for nursing care. The demands in these practical learners make them better prepared to work and independently apply their skills when they graduate and work (Hägg-Martinell, A et al, 2020).

In addition to the view of career life according to Holmgren, J (2017), the professional task of global nurse analysis is the development of knowledge about health, care, disease and ecology in the local and global context. The nursing profile characterizes individuals with advocacy skills, activism and a spirit of sustainable development. The attainment of knowledge in academic education is used in upholding human norms to get society to get social justice. So it can be concluded that nursing knowledge globally aims 


\section{STRADA Jurnal Ilmiah Kesehatan}

DOI: $10.30994 /$ sjik.v9i2.488

ISSN: 2252-3847 (print); 2614-350X (online)

Vol.9 No.2 November 2020 Page.1445-1456

to reduce the morbidity of individuals and communities, maintain human dignity and contribute to health for current and future generations.

The goal of becoming a nurse is pursued in campus and clinical education. In curriculum education on campus students are provided with theoretical knowledge and learn to use laboratory equipment. Apart from being on campus, clinical learners are also carried out in hospitals and health centers. So that nurses are required to be able to work together with a team of nurses and other medical personnel, one of which is a doctor. Based on the results of research on 1,024 samples of nurses. Nurses need effective communication within the nursing team and with doctors. This shows the nurse with high satisfaction if they can work with teams and collaborate with doctors. So it can be concluded that managerial strategies to promote nurse collaboration with the team and with other medical personnel are important to increase the effective commitment of nurses to the team (Galletta, $\mathrm{M}$ et al, 2016).

When undergoing clinical studies, nursing students are also required to adapt and interact in the community of practice. Students are also required to adapt to the culture that exists in the clinic and the patients they treat (Hägg-Martinell, A, et al, 2016). Based on repeated ethnographic observations carried out in disease care units at Swedish educational hospitals in 2011 and 2013 and two years later retrospective interviews were conducted with nurse students, it was found that nurse students learned to adapt to the hospital environment, learned to manage stress to create an adaptive learning environment structure, building therapeutic interaction relationships with patients, practicing independently in the nursing unit, and taking responsibility for nursing care. The demands in these practical learners make them better prepared to work and independently apply their skills when they graduate and work (Hägg-Martinell, A et al, 2020).

The last decade of professional nursing organizations recommended competencybased education to prepare nursing graduates with core competencies so that new graduates can face the realizations of the health system and future health challenges. Several studies have focused on new graduate nurses who are considered competent through competency tests so that when they are working, nurses can use the competencies they have developed in nursing care services. Research conducted by Charette, $\mathrm{M}$ et al (2019) was conducted with 19 individual semi-structured interviews and focus groups of nurses. The research found that competent nurses have the task of developing practices, collaborating professionally in work teams, having management skills, the ability to integrate patients and family in the team, apply scientific practice, increase scientific knowledge and in nursing care nurses use credible practice sources.

The discussion above is the huge demands and duties of nurses towards professional nursing care services, but in practice there are still deficiencies and weaknesses in nursing services. It was found that there was a lack of basic nursing care applied in the service. Nurses agree that evidence-based practice is useful in their clinical practice, but nurses still lack the knowledge to apply it in nursing care practice. The implementation of evidencebased practice in nursing practice is still low. The values of caring, trust and fairness as well as the expected competence in daily practice do not affect belief and implementation of scientific evidence-based practice. So it is necessary to emphasize the importance of increasing the knowledge, skills and competence of nurses in educational studies (SkelaSavič, B, et al 2017).

The possibility of a decrease in nurse performance can be viewed retrospectively in the learning process while in campus and clinical academics. In line with the research that has been carried out using a qualitative lecturer by conducting secondary thematic analysis of 


\section{STRADA Jurnal Ilmiah Kesehatan}

DOI: $10.30994 /$ sjik.v9i2.488

ISSN: 2252-3847 (print); 2614-350X (online)

Vol.9 No.2 November 2020 Page.1445-1456

interview data obtained from a sample of 14 mentors and 16 nursing students, it is found that there is a concern in carrying out clinical learning on student nurses. Most of the supervisors believe that students should be given support, motivation and encouragement in expressing their concerns in nursing learning (Brown, $\mathrm{P}$ et al, 2020).

The duties and demands of being a big nurse require a qualified academic education and are required to create competent nurses. A total of 57 countries have reported a shortage of graduate nursing personnel to facilitate community nursing care in need of health care assistance. One of the causes of the lack of nursing graduates is the lack of faculty which directly affects the adequate number of nursing graduates. Adequate faculties are illustrated by several influencing factors including nursing faculty administrations who are skilled in monitoring teacher needs so as to create positive relationships between teachers and faculty, increase organizational commitment, productivity, job satisfaction and perceived organizational support (Gutierrez AP et al, 2012).

In the assessment of nurses the Cumulative Achievement Index (GPA) can be used as a benchmark for student academic assessment. So that in the process of nursing education, lecturers and students must always monitor the GPA score which is evaluated every semester. The factors that influence the retention and success of nursing students are the support from educational institutions and student families. The ability of learning provider institutions to facilitate peer support, providing safe spaces for learning, supporting learning facilities services such as faculty culture, teaching practices and appropriate curricula. Students need a friendly environment and respect high ethical values. Institutions should have strategies that encourage students to empower themselves in learning, treat each student fairly, facilitate learning and cooperation between institutions to develop student abilities (Shelaine I, et al, 2020). From the problems that have been described above, innovative and creative learning management is needed to create competent nurse graduates.

\section{METHOD}

Based on the research objectives, the research design used was quantitative using a pre-experimental design with the type of one group pre post test. The purpose of this study was to determine changes in the increase in student GPA after the implementation of instructional leadership based on Theory Planned Behavior (TPB) by the Head of the Nursing Undergraduate Study Program for one semester. The total sampling design was all new students of the Nursing Undergraduate Study Program of the Bhakti Wiyata Kediri Institute of Health Sciences totaling 63 students.

The implementation of TPB-based Instructional Leadership carried out by the Head of Study Program contains a guide with 7 components of instructional leadership based on Theory Planned Behavior (TPB) with the following chart: 


\section{STRADA Jurnal Ilmiah Kesehatan}

DOI: $10.30994 /$ sjik.v9i2.488

ISSN: 2252-3847 (print); 2614-350X (online)

Vol.9 No.2 November 2020 Page.1445-1456

\section{Gambar 1. Instructional Leadership berbasis TPB}
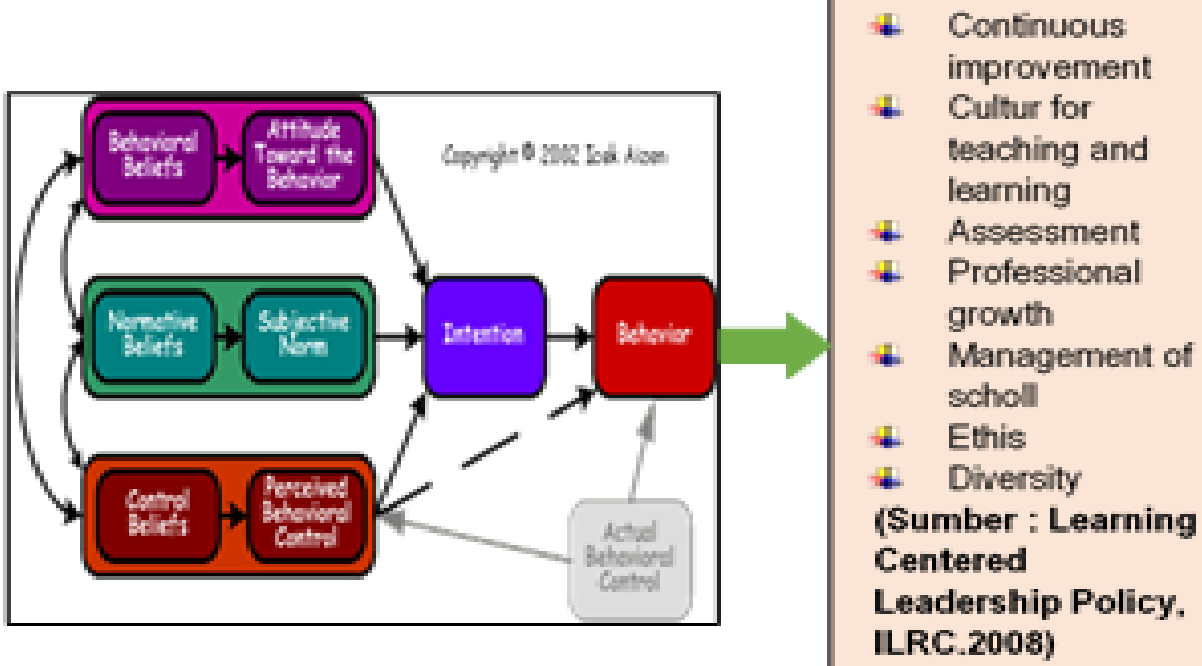

Theory Planned Behavior, which includes 3 things, namely beliefs about possible outcomes and evaluation of these behaviors (behavioral beliefs), beliefs about expected norms and motivation to fulfill these expectations (normative beliefs), and beliefs about factors that can support or hinder behavior and awareness of the power of these factors (control belief). The positive behavior approach of lecturers, students and the academic community in enhancing their respective roles is made in the SOP in which there is a behavioral approach in generating intentions according to the TPB theory. parents, lecturers and the entire academic community.

Table 1. SOP for the application of TPB-based IL

\begin{tabular}{|l|l|}
\hline Behavior belief & $\begin{array}{l}\text { Convincing the academic community (students and lecturers) to carry } \\
\text { out academic activities, believing in being able to overcome every } \\
\text { problem in the academic environment in order to develop study } \\
\text { programs in a sustainable manner }\end{array}$ \\
\hline Normative beliefs & $\begin{array}{l}\text { Convince lecturers to fulfill their hopes of carrying out Tri Dharma } \\
\text { duties with full responsibility and enthusiasm in realizing the vision, } \\
\text { mission and objectives of the study program }\end{array}$ \\
\hline Control beliefs & $\begin{array}{l}\text { Convince the academic community (students and lecturers) to have the } \\
\text { intention, strength and great support in increasing their fulfillment of } \\
\text { their obligations as students and teachers, benefits for personal, future, } \\
\text { parents, nation and religion }\end{array}$ \\
\hline Behavior belief & $\begin{array}{l}\text { Convince the academic community (students and lecturers) that they can } \\
\text { carry out academic activities with a comfortable learning culture and a } \\
\text { healthy academic environment }\end{array}$ \\
\hline Normative beliefs & $\begin{array}{l}\text { Convincing the academic community (students and lecturers) can fulfill } \\
\text { their hopes of developing and maintaining a disciplined learning } \\
\text { environment in a safe, orderly, serene and comfortable manner }\end{array}$ \\
\hline
\end{tabular}




\section{STRADA Jurnal Ilmiah Kesehatan}

DOI: $10.30994 /$ sjik.v9i2.488

ISSN: 2252-3847 (print); 2614-350X (online)

Vol.9 No.2 November 2020 Page.1445-1456

\begin{tabular}{|c|c|}
\hline Control beliefs & $\begin{array}{l}\text { Convince the academic community (students and lecturers) to have the } \\
\text { intention, strength and great support in improving the quality in both } \\
\text { academic and non-academic fields through a comfortable learning } \\
\text { culture and a healthy academic environment. }\end{array}$ \\
\hline Behavior belief & $\begin{array}{l}\text { Convince the academic community (students and lecturers) that it can } \\
\text { improve learning outcomes optimally through evaluation and academic } \\
\text { development carried out by the Head of Study Program continuously }\end{array}$ \\
\hline Normative beliefs & $\begin{array}{l}\text { Convince the academic community (students and lecturers) to believe } \\
\text { that they can fulfill their expectations of improving learning outcomes } \\
\text { through evaluation and ademic development carried out by the Head of } \\
\text { Study Program by developing, planning, and implementing curriculum } \\
\text { and student learning }\end{array}$ \\
\hline Control beliefs & $\begin{array}{l}\text { Convince the academic community (students and lecturers) to have the } \\
\text { intention, strength and great support in increasing learning outcomes and } \\
\text { increasing academic and non-academic achievements. }\end{array}$ \\
\hline Behavior belief & $\begin{array}{l}\text { Convince the academic community (students and lecturers) to be able to } \\
\text { take advantage of the various learning resources available and the Head } \\
\text { of Study Program can fulfill the facilities that need to be provided }\end{array}$ \\
\hline Normative beliefs & $\begin{array}{l}\text { Convince the academic community (students and lecturers) to be able to } \\
\text { fulfill their expectations in utilizing the various learning resources } \\
\text { available and comply with the established campus management }\end{array}$ \\
\hline Control beliefs & $\begin{array}{l}\text { Convince the academic community (students and lecturers) to have great } \\
\text { intention, strength and support in utilizing various learning resources } \\
\text { based on equality, justice, ethics and integrity }\end{array}$ \\
\hline Behavior belief & $\begin{array}{l}\text { Convince the academic community (students and lecturers) to be able to } \\
\text { improve learning success through a learning process that is in } \\
\text { accordance with the ethical standards of campus life } \\
\text { Convince the academic community (students and lecturers) to be able to } \\
\text { improve learning success through a learning process that is in } \\
\text { accordance with the ethical standards of campus life }\end{array}$ \\
\hline Normative beliefs & $\begin{array}{l}\text { Convince the academic community (students and lecturers) to be able to } \\
\text { fulfill their expectations of being role models and providing professional } \\
\text { support in applying professional code of ethics and the values that } \\
\text { become the rules }\end{array}$ \\
\hline Control beliefs & Convince the academic community (students and lecturers) to have great \\
\hline
\end{tabular}




\section{STRADA Jurnal Ilmiah Kesehatan}

DOI: $10.30994 /$ siik.v9i2.488

ISSN: 2252-3847 (print); 2614-350X (online)

Vol.9 No.2 November 2020 Page.1445-1456

\begin{tabular}{|l|l|}
\hline & $\begin{array}{l}\text { intention, strength and support in making decisions in an ethical context } \\
\text { and respecting the dignity of all parties }\end{array}$ \\
\hline Behavior belief & $\begin{array}{l}\text { The Head of Study Program assures lecturers and employees that they } \\
\text { can act fairly towards student backgrounds, do not discriminate in terms } \\
\text { of ethnicity, religion, gender, and origin }\end{array}$ \\
\hline Normative beliefs & $\begin{array}{l}\text { Convince lecturers to live up to their expectations of understanding and } \\
\text { responding effectively to the cultural and ethnic diversity of students } \\
\text { through the togetherness between the Institute and society }\end{array}$ \\
\hline Control beliefs & $\begin{array}{l}\text { Convince the academic community (students and lecturers) to have great } \\
\text { intentions, strength and support in building family communication that } \\
\text { includes lecturers, employees, parents of students in order to strengthen } \\
\text { kinship and improve the quality of education of their children }\end{array}$ \\
\hline
\end{tabular}

\section{RESULTS}

Statistical analysis using SPSS 22. Values are expressed using means, SD and presentation. The data obtained was tested for normality, namely the KolmogorovSmirnov test to assess the normality of the sample, then hypothesis testing for differences in learning motivation before and after the application of TPB-based Instructional Leadership. the dependent t-test is carried out (paired t-test)

Table 2. Distribution of GPA Normality Test Results Before and After the Intervention

\begin{tabular}{llll}
\hline Variabel & Mean & Median & P Value \\
\hline Pre IPK & 3,33316 & 3,3400 & 0,792 \\
\hline Post IPK & 3,4205 & 3,4000 & 0,691 \\
\hline
\end{tabular}

Table 3. Distribution of GPA Normality Test Results After and After the Intervention

\begin{tabular}{lllll}
\hline Variabel & Mean & SD & SE & PValue \\
\hline Pre IPK & - & 0,15548 & 0,01959 & 0,000 \\
&, 08889 & & & \\
\hline
\end{tabular}

Based on the results of the normality test, it was found that the distribution of data was normally distributed with a $\mathrm{p}$ value> 0.05 . The average result of the Grade Point Average (GPA) of undergraduate nursing students after being given the application of TPB-based Instructional Leadership in the Nursing Undergraduate Study Program has increased, with the difference in the average GPA of level 1 students in the undergraduate nursing study program, namely $(3,42047619-3,331587302=0.088888889)$ with the percentage of effectiveness of TPB-based Instructional Leadership on GPA of $2.668 \%$ obtained from (0.088888889: 3.331587302$) \times 100 \%$. It can be concluded that the TPB-based Instructional Leadership intervention is effective $2.668 \%$ in increasing the GPA of the S1 Nursing study program students level 1 for one semester. There was a significant 


\section{STRADA Jurnal Ilmiah Kesehatan}

DOI: $10.30994 /$ sjik.v9i2.488

ISSN: 2252-3847 (print); 2614-350X (online)

Vol.9 No.2 November 2020 Page.1445-1456

difference in the GPA score between before and after the implementation of TPB-based Instructional Leadership, namely $\mathrm{p}>0.05(\mathrm{p}=0.000)$. So it can be concluded that TPBbased Instructional Leadership is effective in increasing the GPA of new undergraduate nursing students.

\section{DISCUSSION}

The success of student studies cannot be separated from professionalism and good academic services. A good academic organization requires a supportive academic and work atmosphere between the faculty organization and the academic community. In a private educational institution, the organizational relationship between the faculty and lecturers is expected to have a good and mutually beneficial organizational relationship. In a study, it was found that individual workers in an organization have a commitment to organizational career (COC) in pursuing a long and successful career. The results of a study conducted by Lapointe E et al (2019) which examined the components of organizational commitment which proved the reliability and validity of the COC components, namely the subdimensions of affective, normative, continuity, career commitment, turnover intention and voluntary turnover. So it is expected that both parties between the organization and the individual have a good and mutually beneficial relationship.

There is also research that assesses the factors that influence the work of nursing faculty members which aims to improve the quality of nursing faculty which is conducted online with 45 item questions including aspects of nursing faculty performance including teaching competence, teacher productivity and organizational support. From the 808 surveys, it was found that several factors influenced the intention of nursing teachers to continue working in academia, including support for developing teachers, support for resources and time for research, recognition or appreciation from the faculty, facilities for teaching needs, monitoring from the faculty in teaching career development. . From the conclusion of the study, the right and appropriate academic administrator is very important to support teacher performance (Candela L et al, 2013).

A nurse in this case can be described as a nursing teacher who also needs social support from supervisors and colleagues in getting clear roles at work. Clarity in working roles is included in high social support from superiors and colleagues. In conclusion, there is an adequate description of roles, through clear and detailed information about the functions, responsibilities, and behaviors expected by nurses in increasing job satisfaction. The implication in nursing academic policy is that managers in this case described by the Head of Study Program must realize that the importance of clarifying the roles, responsibilities and functions of every professional action at work (Orgambídez, A. \& Almeida, H, 2020).

In teaching practice a teacher must be able to understand each individual student, be able to organize classes, have high expectations of learning for students, know and use various strategies that can facilitate student learning, promote, monitor and reflect on learning outcomes (Bishop and Berryman, 2009).

The role of a manager or leader in a study program is needed in improving all the factors needed to improve the quality of education. Developing an active leadership role in particular can increase student success and retention (Crampton, N, et al, 2012). A leader is expected to be responsible, have a role model, influence the team to uphold organizational and professional values. Leaders also have an important role in ensuring that the curriculum is in accordance with the character of professional values (Ann Gallagher, 2010). 


\section{STRADA Jurnal Ilmiah Kesehatan}

DOI: $10.30994 /$ sjik.v9i2.488

ISSN: 2252-3847 (print); 2614-350X (online)

Vol.9 No.2 November 2020 Page.1445-1456

In the field of education, a good leadership role is needed in setting a good educational management strategy. The role of educational leaders is very important for advancement in education. Research conducted by Williams, S.S (2020) found that educational leaders have a big share in designing curricula that are relevant to indigenous local cultures and focus on correlated relationships between countries, places, cultures and communities.

The approach needed by the head of a study program in management is to use Instruction Leadership (IL) which has been proven effective in its implementation. This study investigates the impact of principal IL on educator performance. The research was given to 389 educators in 18 schools. The results showed that IL in achieving the mission, managing the instruction program, developing a positive school learning climate was proven to positively improve the performance of educators. So that stakeholders in the education sector can improve the quality of education through the role of the principal (Hafsat AB et al, 2020). The findings of the approach to using IL found that 28 schools in Singapore stated that Singapore school leaders adopted the IL approach in running school management, IL practices focused on promoting professional development and a positive school climate by increasing the competence of educators.

Empirical research has also been carried out on 247 teachers in Istanbul, Turkey with multiple regression analysis showing the IL behavior of the principal affects teacher collaboration, professional motivation and commitment. The IL behavior of the principal increases adaptive behavior between teachers that contributes to teacher commitment to school progress. In addition to improving the performance and competence of educators, IL also has an impact on increasing student achievement. In line with research conducted by Allison M (2011) found that IL applied by more experienced principals was seen as preferred by teachers, student achievement was higher in schools where principals took part in efforts to improve teaching, it was also found that a decrease in repetition was found. descending grade in lower students. So it can be concluded that the policy of freeing school principals from being responsible and fully participating in managing education management is very important to advance education and student achievement. A qualitative research strategy has also been carried out through interviews with 14 school leaders in the country of Ghana. This study found that the application of IL can improve management-focused teaching supported by behaviorism by instilling a leadership culture run by school principals (Usman Kojo Abonyi \& Francesco Sofo, 2019).

In the implementation of IL in this study carried out using the TPB psychological science approach. Theory Planned Behavior (TPB) is often used to observe the behavior of the academic community in campus culture. Research by De Jonge LPJWM et al (2020) has observed the behavior of clinical supervisors in direct observation of clinical learning conducted by health students. In this study, it was found that the cognitive and emotional processes of the supervisor's intention were measured using the TPB approach and it was found that the supervisor had a positive attitude towards direct observation. Supervisors use past experiences to form intentions in direct observation of student clinical learning carefully, wisely and involve other medical personnel to be involved in the observation.

In line with the research conducted by Hi Y, et al (2020) using TPB to assess the entrepreneurial intention of college students by looking at the correlation between student creativity and entrepreneurial intentions. The results of the study concluded that creativity has a significant effect on entrepreneurial intentions, which is characterized by behavior, subjective norms and entrepreneurial attitudes which significantly affect one's intention in entrepreneurship. Research using the TPB approach has also been carried out in looking at students' perceptual behavior towards future careers which aims to review and design the 


\section{STRADA Jurnal Ilmiah Kesehatan}

DOI: $10.30994 /$ sjik.v9i2.488

ISSN: 2252-3847 (print); 2614-350X (online)

Vol.9 No.2 November 2020 Page.1445-1456

curriculum. Student intention is measured to see how far the student's career views after taking academic education studies. The results of this study serve as guidelines for veterinary education policy makers in increasing knowledge innovation, recruitment of work midwives, and curriculum design. So that it can design better learning management (Feakes AM, et al, 2019). This research can be concluded that it is suitable and proven to be effective in implementing IL which includes an element of increasing the ability of students both academic and non-academic to realize a good career in the future.

Not only in the field of human resources, including the academic community, but meeting the needs of the campus environment also needs to be considered by institutional management. In TPB research it is also often applied to see the domain of environmental science. Research conducted by Si H, et al (2019) conducted a comprehensive bibliometric analysis of TPB studies conducted in the environmental field showing that waste management, green consumption, climate and environment, savings and conservation, and sustainable transportation are the main research topics. So that it is in accordance with one of the objectives of implementing IL in completing facilities and infrastructure to support campus facilities.

\section{CONCLUSIONS}

The role of the Head of the Study Program is very important in the management of the study program management. The Head of Study Program is required to make a policy and management design that aims to develop human resources for lecturers and improve student academic and non-academic achievements. The implementation of TPB-based IL has proven to be effective in improving student academic achievement so that it is expected to be an input for academic stakeholders in implementing this management system in developing study programs.

\section{REFERESI}

Allison M. Borden (2011) Relationships between Paraguayan principals' characteristics, teachers' perceptions of instructional leadership and school outcomes, International Journal of Leadership in Education, 14:2, 203227, DOI: $10.1080 / 13603124.2010 .482675$

Ann Gallagher, Verena Tschudin, Educating for ethical leadership, Nurse Education Today, Volume 30, Issue 3, 2010, Pages 224-227, ISSN 0260-6917, https://doi.org/10.1016/j.nedt.2009.11.003.

(http://www.sciencedirect.com/science/article/pii/S0260691709002159)

Bishop and Berryman, 2009. The Te Kotahitanga effective teaching profile. Set: Research Information for Teachers, 2 (2) (2009) https://www.nzcer.org.nz/system/files/journals/set/downloads/set2009_2_027_0.p df

Brown, P, Jones, A, Davies, J. Shall I tell my mentor? Exploring the mentor-student relationship and its impact on students' raising concerns on clinical placement. $J$ Clin Nurs. 2020; 29: 3298- 3310. https://doi.org/10.1111/jocn.15356

Candela L, Gutierrez A, Keating S. A national survey examining the professional work life of today's nursing faculty. Nurse Educ Today. 2013;33(8):853-859. doi:10.1016/j.nedt.2012.10.004

Cath Wilson, Liesl Heinrich, Parvaneh Heidari, Karen Adams, Action research to implement an Indigenous health curriculum framework, Nurse Education Today, Volume $\quad 91, \quad 2020, \quad 104464, \quad$ ISSN $0260-6917$, 


\section{STRADA Jurnal Ilmiah Kesehatan}

DOI: $10.30994 /$ sjik.v9i2.488

ISSN: 2252-3847 (print); 2614-350X (online)

Vol.9 No.2 November 2020 Page.1445-1456

https://doi.org/10.1016/j.nedt.2020.104464.

(http://www.sciencedirect.com/science/article/pii/S0260691719318726)

Charette, M., Goudreau, J., \& Bourbonnais, A. (2019). How do new graduated nurses from a competency-based program demonstrate their competencies? A focused ethnography of acute care settings. Nurse education today, 79, 161-167. https://doi.org/10.1016/j.nedt.2019.05.031

Crampton, N. Weaver, A. Howard. Holding a mirror to society? The sociodemographic characteristics of the University of Otago's health professional students N. Z. Med. J., 125 (1361) (2012),pp. 12-28. https://assets-global.websitefiles.com/5e332a62c703f653182faf47/5e332a62c703f66e362fdd5e_crampton.pdf

De Jonge LPJWM, Mesters I, Govaerts MJB, Timmerman AA, Muris JWM, Kramer AWM, van der Vleuten CPM. Supervisors' intention to observe clinical task performance: an exploratory study using the theory of planned behaviour during postgraduate medical training. BMC Med Educ. 2020 Apr 30;20(1):134. doi: 10.1186/s12909-020-02047-y. PMID: 32354331; PMCID: PMC7193388.

Dong Nguyen, David Ng, Wenshu Luo \& Syifaa' Mansor (2020) Exploring the relationships between instructional leadership and teacher competences: Singapore primary school teachers' perceptions, International Journal of Leadership in Education, DOI: 10.1080/13603124.2020.1731765

Feakes AM, Palmer EJ, Petrovski KR, Thomsen DA, Hyams JH, Cake MA, Webster B, Barber SR. Predicting career sector intent and the theory of planned behaviour: survey findings from Australian veterinary science students. BMC Vet Res. 2019 Jan 15;15(1):27. doi: 10.1186/s12917-018-1725-4. PMID: 30646904; PMCID: PMC6334407.

Galletta, M., Portoghese, I., Carta, M.G., D'Aloja, E. and Campagna, M. (2016), The Effect of Nurse-Physician Collaboration on Job Satisfaction, Team Commitment, and Turnover Intention in Nurses. Res Nurs Health, 39: 375-385. doi:10.1002/nur.21733

Gutierrez AP, Candela LL, Carver L. The structural relationships between organizational commitment, global job satisfaction, developmental experiences, work values, organizational support, and person-organization fit among nursing faculty. $J A d v$ Nurs.2012;68(7):1601-1614. doi:10.1111/j.1365-2648.2012.05990.

Hafsat Aliyu Bada, Tengku Faekah Tengku Ariffin \& Hasniza Binti Nordin (2020) The Effectiveness of Teachers in Nigerian Secondary Schools: The Role of Instructional Leadership of Principals, International Journal of Leadership inEducation, DOI: 10.1080/13603124.2020.1811899

Hägg-Martinell A, Tegnestedt C, Larsen J. Nurse Students' Thoughts on a Sustainable Professional Life as Nurses: A Qualitative Study. Adv Med Educ Pract. 2020 Apr 15;11:295-303. doi: 10.2147/AMEP.S245877. PMID: 32346320; PMCID: PMC7167258.

Hägg-Martinell, A., Hult, H., Henriksson, P., \& Kiessling, A. (2016). Community of practice and student interaction at an acute medical ward: An ethnographic study. Medical teacher, 38(8),793-800. https://doi.org/10.3109/0142159X.2015.1104411

Hi Y, Yuan T, Bell R, Wang J. Investigating the Relationship Between Creativity and Entrepreneurial Intention: The Moderating Role of Creativity in the Theory of Planned Behavior. Front Psychol. 2020 Jun 9;11:1209. doi: 10.3389/fpsyg.2020.01209. PMID: 32581972; PMCID: PMC7296068. 


\section{STRADA Jurnal Ilmiah Kesehatan}

DOI: $10.30994 /$ sjik.v9i2.488

ISSN: 2252-3847 (print); 2614-350X (online)

Vol.9 No.2 November 2020 Page.1445-1456

Holmgren, J. (2017) 'Global nursing: Educating future nurses for tomorrow's nursing care needs', Nordic. Journal of Nursing Research, 37(3), pp. 172-174. doi: $10.1177 / 2057158517716504$

Lapointe, É., Vandenberghe, C., Mignonac, K., Panaccio, A., Schwarz, G., Richebé, N. and Roussel, P. (2019), Development and validation of a commitment to organizational career scale: At the crossroads of individuals' career aspirations and organizations' needs. J Occup Organ Psychol, 92: 897-930. doi:10.1111/joop.12273

Orgambídez, A. \& Almeida, H. (2020) Social support, role clarity and job satisfaction: a successful combination for nurses. International Nursing Review 00, 1-7 https://doi.org/10.1111/inr.12591

Ramazan Cansoy, Hanifi Parlar \& Mahmut Polatcan (2020) Collective teacher efficacy as a mediator in the relationship between instructional leadership and teacher commitment, International Journal of Leadership in Education, DOI: 10.1080/13603124.2019.1708470

Si H, Shi JG, Tang D, Wen S, Miao W, Duan K. Application of the Theory of Planned Behavior in Environmental Science: A Comprehensive Bibliometric Analysis. Int J Environ Res Public Health. 2019 Aug 4;16(15):2788. doi: 10.3390/ijerph16152788. PMID: 31382712; PMCID: PMC6695987.

Shelaine I. Zambas, Sophia Dutch, Debra Gerrard. Factors influencing Māori student nurse retention and success: An integrative literature review, Nurse Education Today, Volume $\quad 91, \quad 2020, \quad 104477, \quad$ ISSN $0260-6917$, https://doi.org/10.1016/j.nedt.2020.104477.

(http://www.sciencedirect.com/science/article/pii/S0260691719313085)

Skela-Savič, B., Hvalič-Touzery, S., \& Pesjak, K. (2017). Professional values and competencies as explanatory factors for the use of evidence-based practice in nursing. Journal of advanced nursing, 73(8), 1910-1923. https://doi.org/10.1111/jan.13280 